\title{
Morphological dietary composition of Antarctic toothfish (Dissostichus mawsoni) along the East Antarctic continental slope
}

Gi Chang Seong ( $\sim$ sgc0720@naver.com)

Gyeongsang National University

\section{Seok-Gwan Choi}

National Institute of Fisheries Science

\section{Sangdeok Chung}

National Institute of Fisheries Science

Doo Hae An

National Institute of Fisheries Science

Hyun-Woo Kim

Pukyong National University

Gun Wook Baeck

Gyeongsang National University

\section{Original Paper}

Keywords: Dissostichus mawsoni, Nototheniidae, Antarctic toothfish, Diet composition

Posted Date: February 10th, 2021

DOI: https://doi.org/10.21203/rs.3.rs-166624/v1

License: (1) This work is licensed under a Creative Commons Attribution 4.0 International License.

Read Full License

Version of Record: A version of this preprint was published at Polar Biology on February 16th, 2021. See the published version at https://doi.org/10.1007/s00300-021-02820-9. 


\section{Abstract}

To predict how the fishing of Antarctic toothfish, Dissostichus mawsoni, would affect the ecosystem, it is necessary to understand the species' ecological niche. Morphological analysis of the stomach contents of $960 \mathrm{D}$. mawsoni specimens collected at depths of 946-1,600 m along the East Antarctic continental slope from December 2016 to March 2017 was used to assess dietary composition according to depth, sex, site, and size. Fishes were the most common prey item for $D$. mawsoni , comprising $97.8 \%$ based on the index of relative importance. Among the nine fish families consumed by $D$. mawsoni, Macrouridae was the dominant taxon. The size of $D$. mawsoni increased with depth. The dietary composition of $D$. mawsoni did not show significant differences by depth or sex, but did differ with site and size. D . mawsoni was the top predator in the ecosystem along the East Antarctic continental slope and can be considered an opportunistic feeder, feeding on abundant food in the environment. Therefore, additional studies of the diet of Antarctic toothfish are necessary to maintain the ecosystem structure and function in a changing environment, and the results of this study can be used as a monitoring baseline.

\section{Introduction}

The Antarctic toothfish, Dissostichus mawsoni, belongs to the family Nototheniidae and is endemic to the seas of Antarctica, generally distributed in waters with subzero temperatures south of $60^{\circ} \mathrm{S}$ latitude (Gon and Heemstra 1990; Goldsworthy et al. 2002). D. mawsoni can grow to more than $2 \mathrm{~m}$ in length, weigh in excess of $100 \mathrm{~kg}$, and live for more than 30 years (Brooks et al. 2011; Hanchet et al. 2015). It can be found from shallow shelf waters to depths of at least 2,200 $\mathrm{m}$. They are both the top fish predator in the Antarctic Ocean ecosystem and a prey of whales and seals, and thus have a strong impact on other species as well as being an ecologically and economically important fishery resource in Antarctic waters (Calhaem and Christoffel 1969; Yukhov 1971; Barrera-Oro et al. 2005; Ainley and Pauly 2014; Pinkerton and Bradford-Grieve 2014).

A longline fishery for D. mawsoni in the East Antarctic Ocean (Area 58.4.1 and 58.4.2) has been active since 2003, with a maximum D. mawsoni catch of 910 tons in 2005, a minimum of 52 tons in 2013, and a most recent report of 308 tons in 2018. The Commission for the Conservation of Antarctic Marine Living Resources (CCAMLR) manages resources by setting catch limits, conducting stock assessments, and using a precautionary approach to ensure that the stocks of $D$. mawsoni are not affected by fishing. However, the 58 Areas are categorized as lacking scientific data for management of toothfish stocks. Therefore, to support continued harvest of $D$. mawsoni in the 58 Areas, ecological data for stock assessment and management should be collected.

Knowledge of the trophic dynamics of fish species is very useful for understanding the biological and ecological aspects of target species to sustainably manage fish resources (Collins et al. 2007; Huh et al. 2010; Huh et al. 2012). Thus, data on the trophic ecology of D. mawsoni are necessary for both clarifying ecosystem functions in the Antarctic Ocean and commercial management of the fish. Several studies of the diet of D. mawsoni have been conducted in Areas 48 and 88 including McMurdo Sound (Calhaem and 
Christoffel 1969), an open Pacific sector of Antarctic water (Yukhov 1971), the Ross Sea (Fenaughty et al. 2003; Kokorin 2010; Stevens et al. 2014), South Sandwich Islands (Roberts et al. 2011), and Lazarev Sea (Petrov and Tatarnikov 2011), as well as Areas 58, including the Cosmonaut Sea (Pakhomov and Tseytlin 1992) and Subarea 58.4.1(Park et al. 2015; Yoon et al. 2017).

Therefore, this study compiled ecological data to clarify ecosystem structure and functions based on the morphological analyses of the stomach contents of $D$. mawsoni along the East Antarctic continental slope, considering main prey items and variations in diet composition with depth, sex, site, and size.

\section{Materials And Methods}

The 960 D. mawsoni samples used in this study were collected from along the East Antarctic continental slope from December 2016 to March 2017 at depths of 946-1,660 m with bottom longlines using bait of Humboldt squid (Dosidicus gigas) and Pacific herring (Clupea pallasii) by the Kingstar commercial vessel (Fig. 1). The bait used for bottom longline sampling was not considered in subsequent analyses.

The body length $(\mathrm{BL})$ and wet body weight of $D$. mawsoni were measured to the nearest centimeter and gram, respectively, by the on-board Korean scientific observer. The sampled stomachs were preserved by freezing immediately after extraction, and then taken to the laboratory. Stomach contents were identified to the lowest taxonomic level possible under a dissecting microscope. The status of prey digestion was categorized as fresh, slightly digested, and digested, and the beaks of cephalopods and otoliths of fishes were included in subsequent analysis. The numbers (individuals) and wet weights (g) of each prey item were determined.

Diet was quantified based on frequency of occurrence $(\% F)$, numerical percentage $(\% N)$, and wet weight percentage $(\% W)$, which were calculated using the following equations.

$$
\begin{gathered}
\% F=\frac{A_{i}}{N} \times 100 \\
\% N=\frac{N_{i}}{N_{\text {total }}} \times 100 \\
\% W=\frac{W_{i}}{W_{\text {total }}} \times 100
\end{gathered}
$$

where $A_{i}$ is the number of fish preying on species $i, N$ is the total number of fish examined (excluding individuals with empty stomachs), $N_{i}\left(W_{i}\right)$ is the number (wet weight) of prey species $i$, and $N_{\text {total }}\left(W_{\text {total }}\right)$ is the total number (wet weight) of prey. Then the index of relative importance (IRl; Pinkas et al. 1971) was calculated for each prey type, as follows:

$$
I R I=(\% N+\% W) \times \% F
$$


and expressed as a percentage (\%IRI):

$$
\% I R I=\frac{I R I_{i}}{\sum_{i=1}^{n} I R I} \times 100
$$

where $n$ is the total number of prey categories considered at a given taxonomic level.

Size-related dietary changes were examined by dividing the $D$. mawsoni specimens into five size classes: $<100 \mathrm{~cm}, 100-120 \mathrm{~cm}, 120-140 \mathrm{~cm}, 140-160 \mathrm{~cm}$, and $\geq 160 \mathrm{~cm}$. The mean number of prey items per stomach $(\mathrm{mN} / \mathrm{ST})$ ) and mean wet weight of prey items per stomach $(\mathrm{mW} / \mathrm{ST})$ were used to characterize size-related changes in the diet via one-way analysis of variance (ANOVA). Statistical tests were conducted using Excel 2014 for Windows; statistical differences were determined based on a significance level of 0.05 .

Diet overlap between size classes of $D$. mawsoni was estimated from the mass of prey items using the Schoener overlap index $\left(C_{x y}\right)$, expressed as:

$$
\% I R I=\frac{I R I_{i}}{\sum_{i=1}^{n} I R I} \times 100
$$

where $C_{x y}$ is the overlap index and $P_{x i}$ and $P_{y i}$ are the relative proportions of each prey item $i$ of $n$ total prey items found in the stomachs of the $x$ and $y$ size classes of $D$. mawsoni, respectively (Schoener 1970). Values of $C_{x y}>60 \%$ indicated a high degree of overlap (Wallace 1981).

\section{Results}

In total, 960 D. mawsoni specimens ranging from 65 to $187 \mathrm{~cm} \mathrm{BL}$ were collected from along the East Antarctic continental slope during the study period (Fig. 2). Among the 960 stomachs examined, 330 (34.4\%) were empty.

A total of nine prey taxa were found in the remaining 630 stomachs (Table 1). Fishes were the most common prey item for $D$. mawsoni, comprising $92.5 \%$ in terms of occurrence in the diet, $77.8 \%$ in terms of number, $94.5 \%$ of weight, and $97.8 \%$ of IRI. At least nine fish families were identified. Among these families, Macrouridae was the dominant taxon, making up 39.8\% of occurrences, $27.6 \%$ of prey number, and $61.1 \%$ of the diet by weight. Chionobathyscus dewitti in the Channichthyidae was the second largest dietary component, constituting $12.1 \%$ of occurrences, $9.7 \%$ of number, and $11.1 \%$ of weight in the diet of D. mawsoni. Mollusks, stones, crustaceans, and other prey accounted for only $1.9 \%, 0.1 \%, 0.1 \%$, and $0.1 \%$ of the diet by $I R I$, respectively.

The BLs of $D$. mawsoni collected at depths of $<1,000 \mathrm{~m}, 1,000-1,500 \mathrm{~m}$, and $\geq 1,500 \mathrm{~m}$, were $85-163 \mathrm{~cm}$ ( $n=20), 65-183 \mathrm{~cm}(n=623)$, and 98-187 cm ( $n=317)$, respectively. The size of $D$. mawsoni increased 
with depth, with mean BLs of $128.2 \mathrm{~cm}$ at depths $<1,000 \mathrm{~m}, 141.0 \mathrm{~cm}$ at $1,000-1,500 \mathrm{~m}$, and $146.2 \mathrm{~cm}$ at $\geq 1,500 \mathrm{~m}$. Fishes were the dominant prey item at all depths, representing $99.1 \%$ for $D$. mawsoni collected $<1,000 \mathrm{~m}, 98.2 \%$ for those from $1,000-1,500 \mathrm{~m}$, and $96.6 \%$ at $\geq 1,500 \mathrm{~m}$ based on \% IRI. Macrouridae were consumed at all depths, and had \%IR/values of $69.0 \%, 86.6 \%$, and $96.1 \%$ of $D$. mawsoni collected at $<1,000 \mathrm{~m}, 1,000-1,500 \mathrm{~m}$, and $\geq 1,500 \mathrm{~m}$, respectively (Fig. 3). Macrouridae were the dominant prey at all depths, and the proportion of macrourids in the collected $D$. mawsoni increased with increasing depth. Channichthyidae were also consumed at all depths, with $\% I R /$ values of $25.7 \%, 9.7 \%$, and $2.8 \%$ for $D$. mawsoni collected at $<1,000 \mathrm{~m}, 1,000-1,500 \mathrm{~m}$, and $\geq 1,500 \mathrm{~m}$, respectively. Nototheniidae were consumed at all depths, with \% IR/values of $4.7 \%, 3.5 \%$, and $0.8 \%$ for $D$. mawsoni collected at $<1,000 \mathrm{~m}$, $1,000-1,500 \mathrm{~m}$, and $\geq 1,500 \mathrm{~m}$, respectively. The proportion of Channichthyidae and Nototheniidae in the collected $D$. mawsoni decreased with increasing depth.

The BLs of female and male $D$. mawsoni collected during the survey period were $65-187 \mathrm{~cm}(n=539)$ and $76-180 \mathrm{~cm}(n=419)$, respectively, and the sex ratio was 1.3:1. Fishes were the dominant prey items of female and male D. mawsoni, representing $97.7 \%$ of the diet for females and $98.0 \%$ of the diet for males based on \% IRI. Mollusks, in particular cephalopods, were the second most prominent prey items for female and male $D$. mawsoni, with $\% I R /$ values of $2.0 \%$ and $1.8 \%$ for females and males, respectively. Macrouridae were the dominant prey of $D$. mawsoni females and males, with $\% I R /$ values of $90.9 \%$ and $88.4 \%$ for females and males, respectively (Fig. 4). Channichthyidae were also consumed by D. mawsoni females and males, with \% IR/values of $6.4 \%$ and $9.1 \%$ for females and males, respectively. Finally, Nototheniidae were consumed by both $D$. mawsoni females and males, with \% IR/values of $2.5 \%$ and $2.2 \%$ for females and males, respectively.

The BLs of $D$. mawsoni collected at sites A $\left(75^{\circ} \mathrm{E}, 66^{\circ} \mathrm{S}\right), \mathrm{B}\left(97-99^{\circ} \mathrm{E}, 63-64^{\circ} \mathrm{S}\right), \mathrm{C}\left(112-114^{\circ} \mathrm{E}, 64-65^{\circ} \mathrm{S}\right)$, and $\mathrm{D}\left(137-139^{\circ} \mathrm{E}, 66^{\circ} \mathrm{S}\right)$ were $70-163 \mathrm{~cm}(n=52), 110-182 \mathrm{~cm}(n=200), 65-187 \mathrm{~cm}(n=468)$, and 76$180 \mathrm{~cm}(n=240)$, respectively. Fishes were the dominant prey item at all sites, representing $90.7 \%, 96.1 \%$, $98.1 \%$, and $98.8 \%$ for D. mawsoni collected from sites A, B, C, and D, respectively, based on \%IRI. Mollusks, in particular cephalopods, were the second most prominent prey item at all sites, with \% IRI values of $8.4 \%, 3.5 \%, 1.6 \%$, and $1.0 \%$ for $D$. mawsoni collected from sites $A, B, C$, and $D$, respectively. Macrouridae were consumed, and were the dominant prey, at sites $B, C$, and $D$, with \% IR/values of $99.1 \%$, $93.1 \%$, and $84.1 \%$ for D. mawsoni collected from sites B, C, and D, respectively (Fig. 5). Finally, Channichthyidae were consumed at all sites, with \% IR/values of $92.8 \%, 0.3 \%, 5.9 \%$, and $7.4 \%$ for $D$. mawsoni collected from sites $A, B, C$, and $D$, respectively; this group was the dominant prey item at site $A$.

Fishes were the dominant prey item in all size classes, representing $96.9 \%$ of the diet for toothfish $<100$ $\mathrm{cm}, 95.1 \%$ for those $120-140 \mathrm{~cm}, 97.6 \%$ for $120-140 \mathrm{~cm}, 97.9 \%$ for $140-160 \mathrm{~cm}$, and $97.3 \%$ for $\geq 160$ $\mathrm{cm}$ based on \% IRI. Mollusks, in particular cephalopods, were the second most prominent prey item in all size classes, representing $3.1 \%$ of the diet for toothfish $<100 \mathrm{~cm}, 4.7 \%$ for $100-120 \mathrm{~cm}, 2.1 \%$ for $120-140$ $\mathrm{cm}, 1.6 \%$ for $140-160 \mathrm{~cm}$, and $2.1 \%$ for those $\geq 160 \mathrm{~cm}$ based on \% IRI. Macrouridae were consumed by all size classes, representing $12.8 \%$ of the diet for toothfish $<100 \mathrm{~cm}, 71.9 \%$ for $100-120 \mathrm{~cm}, 82.2 \%$ for $120-140 \mathrm{~cm}, 90.1 \%$ for $140-160 \mathrm{~cm}$, and $98.6 \%$ for those $\geq 160 \mathrm{~cm}$ based on \%/RI (Fig. 6). Macrouridae 
were the dominant prey in the four largest size classes, and the proportion of macrourids increased with increasing $D$. mawsoni size. Channichthyidae were also consumed by all size classes, representing $51.3 \%$ of the diet for $D$. mawsoni $<100 \mathrm{~cm}, 9.8 \%$ for $100-120 \mathrm{~cm}, 14.9 \%$ for $120-140 \mathrm{~cm}, 7.4 \%$ for $140-160 \mathrm{~cm}$, and $0.8 \%$ for $\geq 160 \mathrm{~cm}$ based on $\% I R I$. This group was the dominant prey item for the size class of $<100$ $\mathrm{cm}$, and the proportion of Channichthyidae decreased with increasing D. mawsoni $\mathrm{BL}$ (except for the $100-120 \mathrm{~cm}$ size class). Nototheniidae were consumed by all size classes, representing $35.8 \%$ of the diet of those $<100 \mathrm{~cm}, 16.8 \%$ for $100-120 \mathrm{~cm}, 2.6 \%$ for $120-140 \mathrm{~cm}, 2.3 \%$ for $140-160 \mathrm{~cm}$, and $0.4 \%$ for $\geq 160 \mathrm{~cm}$ based on \%IRI. The proportion of Nototheniidae decreased as the BL of $D$. mawsoni increased.

The $m W / S T$ (one-way ANOVA, $\mathrm{F}_{4,933}=5.518, P=0.0002$ ) significantly increased with $\mathrm{BL}$, whereas the $m N / S T$ (one-way ANOVA, $F_{4,933}=1.942, P=0.1014$ ) did not significantly differ among size classes (Fig. 7).

Diet overlap in terms of total prey was examined among size classes of D. mawsoni (Table 2), and significant overlap of more than 0.90 was found among all size classes. Diet overlap of the dominant prey item (fishes) was examined among size classes of $D$. mawsoni (Table 2), and a nonsignificant overlap of less than 0.59 was obtained between the smallest size class $(<100 \mathrm{~cm})$ and the other classes, $100-120 \mathrm{~cm}, 120-140 \mathrm{~cm}, 140-160 \mathrm{~cm}$, and $\geq 160 \mathrm{~cm}$. However, overlap was significant, at more than 0.63 , among the $100-120 \mathrm{~cm}, 120-140 \mathrm{~cm}, 140-160 \mathrm{~cm}$, and $\geq 160 \mathrm{~cm}$ classes.

\section{Discussion}

The most common prey item of $D$. mawsoni was fishes, and among them, the dominant taxon was Macrouridae, followed by Channichthyidae and Nototheniidae. Fishes are high in nutritional value and are often the most abundant prey item of predatory fishes, in particular for Antarctic fishes $>40-50 \mathrm{~cm}$ in total length (TL; Kock 1992). Macrouridae, Channichthyidae and Nototheniidae are typically assumed to be demersal in habit, as is D. mawsoni (Gon and Heemstra 1990). Macrouridae contains more than 300 species, occurs mainly in depths $200-2,000 \mathrm{~m}$, and is the dominant benthopelagic deep-sea fish family in terms of species diversity as well as biomass (Marshall 1965; McLellan 1977). Pinkerton et al. (2013) reported that macrourids appeared abundantly at depths of 900-1,900 in the Ross Sea region. In addition, Macrouridae are an important bycatch species in longline $D$. mawsoni fisheries, and were the most frequently collected bycatch species in the research area during the fishing season in which samples were collected. Roberts et al. (2011) reported that bycatch species could also be eaten by toothfish after they had been hooked as bycatch. Therefore, Macrouridae are thought to have been the dominant prey both because they inhabited depths similar to those from which $D$. mawsoni were collected in this study, and because $D$. mawsoni fed on bycatch species.

According to prior research, D. mawsoni and Dissostichus eleginoides eat, among other items, penguins, seabirds, cephalopods, and fishing discards including pectoral fins, caudal fins, intestines, and male gonads from large nototheniids (Fenaughty et al. 2003; Roberts et al. 2011; Petrov and Tatarnikov 2011; Stevens et al. 2014). In this study, the remains of Emperor Penguin (Aptenodytes forsteri), seabirds, and bones of Mammalia were found in the stomach contents of $D$. mawsoni. Emperor Penguins have a 
circumpolar distribution around Antarctica and dive up to $534 \mathrm{~m}$ for prey (Kooyman and Kooyman 1995; Fretwell et al. 2012). However, the Emperor Penguin observed in this study was a chick and the catch depth of the $D$. mawsoni individual that consumed the emperor penguin was 1,223 $\mathrm{m}$. Therefore, $D$. mawsoni likely preyed on the remains of Emperor Penguin and seabirds that had previously sunk. These results suggest that $D$. mawsoni may obtain a substantial portion of its diet from scavenging, as has been noted in other diet studies (Roberts et al. 2011; Stevens et al. 2014). In this study, Anthozoa, Echinodermata, and stones also appeared in the stomach contents of $D$. mawsoni, and it has been reported that macroalgae, coral fragments, ophiuroids, and stones are swallowed during the process of feeding on benthic prey (Roberts et al. 2011; Stevens et al. 2014).

D. mawsoni inhabits shallow waters such as the surface during its pelagic larval phase, and matures to inhabit continental slopes of about 2,000 m (Evseenko et al. 1995; Hanchet et al. 2010). Yates et al. (2019) reported that the mean weight and proportion of fish that were mature both increased with depth, indicating a gradual migration from shallow to deep waters as fish grow. These patterns were suggested to be the result of multiple ecological processes, including competition, morphological and physiological changes, diet shifts, predator avoidance, and reproductive activity (Péron et al. 2016). In this study, the BL of $D$. mawsoni increased with depth, as has been noted in other diet studies, and it was found that Macrouridae fish dominated at all depths. According to previous studies, D. mawsoni collected at depths of 935-1,515 $\mathrm{m}$ in Subarea 58.4.1 preyed mainly on Macrouridae and Channichthyidae (Yoon et al. 2017), but D. mawsoni collected at depths of 300-350 m in the Cosmonaut Sea (Pakhomov and Tseytlin 1992) preyed mainly on Nototheniidae. Therefore, mawsoni utilize a broad range of habitats throughout their lifespan, and dietary composition by depth is thought to be affected by the size of $D$. mawsoni and the abundance of prey at each depth. Additional dietary studies in nursery areas such as Prydz Bay and spawning areas such as Gunnerus Ridge, BANZARE Bank, and Bruce Rise Plateau are necessary to understand the role of D. mawsoni in the ecosystem of the East Antarctic Ocean (Taki et al. 2011; Yates et al. 2019).

In this study, both female and male $D$. mawsoni preyed mainly on fishes. Among the fishes, Macrouridae, Channichthyidae, and Nototheniidae were the dominant prey, and there was no difference in dietary composition between sexes. According to previous studies, D. eleginoides in the South Atlantic showed differences in dietary composition by site, but there was no significant difference between females and males (de la Rosa et al. 1997; Pilling et al. 2001). These findings suggest that the sex of $D$. mawsoni does not significantly affect dietary composition.

In this study, Channichthyidae were the dominant prey for $D$. mawsoni collected at site $\mathrm{A}$, whereas Macrouridae were the dominant prey at sites $\mathrm{B}, \mathrm{C}$, and $\mathrm{D}$. According to previous research, $D$. mawsoni preys mainly on Macrouridae and Channichthyidae (Fenaughty et al. 2003; Kokorin 2010; Stevens et al. 2014) in the Ross Sea, Channichthyidae and cephalopods in the Lazarev Sea (Petrov and Tatarnikov 2011), and Macrouridae and cephalopods in the South Sandwich Islands (Roberts et al. 2011). In addition, the main prey of $D$. mawsoni in the same study area were Macrouridae and Channichthyidae (Park et al. 2015; Yoon et al. 2017). Thus, D. mawsoni is a carnivorous fish that preys mainly on fishes 
and cephalopods, but shows different prey species preferences depending on the area. Therefore, $D$. mawsoni can be considered an opportunistic feeder, feeding on prey items that are abundant in a given area.

D. mawsoni and eleginoides prey primarily on relatively large and diverse animals, including Macrouridae, Moridae, Rajidae, and Kondakovia longimana, as they develop, after preying on relatively small Nototheniidae such as Patagonotothen guntheri, Lepidonotothen spp., and Pleuragramma antarcticum in the early stages of growth (de la Rosa et al. 1997; Pilling et al. 2001; Goldsworthy et al. 2002; Xavier et al. 2002; Fenaughty et al. 2003; Collins et al. 2007). Both sub-adult ( $<110 \mathrm{~cm} \mathrm{TL})$ and adult ( $\geq 110 \mathrm{~cm} \mathrm{TL}) D$. mawsoni in the Ross Sea prey mainly on fishes and cephalopods, while sub-adults also prey on smaller Channichthyidae, Nototheniidae such as Trematomus spp., and Bathydraconidae such as Bathydraco spp., and adults also prey on larger Macrouridae (Stevens et al. 2014). In addition, in the Falkland Islands, small $D$. eleginoides ( $<40 \mathrm{~cm} \mathrm{TL}$ ) preyed mainly on the small fishes Patagonotothen ramsayi and Loligo gahi, medium $D$. eleginoides preyed also on (40-60 cm TL) P. ramsayi and L. gahi, and large $D$. eleginoides $(>60 \mathrm{~cm}$ TL) preyed on large Micromesistius australis and Macruronus magellanicus (Arkhipkin et al. 2003). In this study, D. mawsoni preyed on Channichthyidae and Macrouridae at $<100$ $\mathrm{cm}$, and as $D$. mawsoni BL increased, the consumption of Channichthyidae and Nototheniidae decreased while that of Macrouridae increased. The $\mathrm{mW} / \mathrm{ST}$ also increased significantly with $\mathrm{BL}$ of $D$. mawsoni. These changes are thought to arise because as $D$. mawsoni grows, the size of the stomach and mouth increase (Gerking 1994), and because increasing energy demands can be attained with greater energy efficiency by preying on a smaller number of larger prey such as Macrouridae than by increasing the number of small prey such as Channichthyidae and Nototheniidae.

D. mawsoniare top predators in deep-sea ecosystems, affecting the size and population dynamics of prey species through predation (Drazen and Sutton 2017; Sallaberry-Pincheira et al. 2018). However, the D. mawsoni fishery not only causes a trophic cascade by removing top predators but also, via bycatch, reduces the population of fish such as Macrouridae, Channichthyidae, Nototheniidae, and Rajidae, which are the main prey of D. mawsoni (Kock 2001; Pinkerton et al. 2010; Jo et al. 2013; Ainley and Pauly 2014; Pinkerton and Bradford-Grieve 2014; Park et al. 2015). Therefore, to manage $D$. mawsoni stocks, CCAMLR developed a precautionary approach that considers all variables affecting the ecosystem and maintains integrated stock assessment and catch limits (Hanchet et al. 2015). The understanding of trophic dynamics can identify predator-prey interactions, estimate prey species biomass, and predict how the toothfish fishery will affect the ecosystem (Melnychuk et al. 2017; Sallaberry-Pincheira et al. 2018). This study analyzed dietary composition by depth, sex, site, and size through morphological analysis of the stomach contents of $D$. mawsoni collected along the East Antarctic continental slopes. However, $D$. mawsoni is an opportunistic feeder, and studies may show biased results due to differences in prey availability depending on spatial and temporal variation (Stevens et al. 2014; Park et al. 2015). In conclusion, to maintain ecosystem structure and function throughout the East Antarctic Ocean, additional studies on diet should be conducted, and this study can be used as a baseline to monitor changing environments in the future. 


\section{Declarations}

The English in this document has been checked by at least two professional editors, both native speakers of English. For a certificate, please see:http://www.textcheck.com/certificate/Aw9HNj

Acknowledgments We thank the captain and crew of the commercial fishing vessel Kingstar for the sample collection. We appreciate Dieter Piepenburg, Keith Reid, and two anonymous reviewers for their fruitful comments that greatly improved the paper. This research was supported by the National Institute of Fisheries Science (Republic of Korea) (R2021029).

Author contributions GWB, SGC, SDC, and DHA designed this study. GCS, GWB, and HWK conducted the experiments. GCS and GWB wrote the manuscript, and prepared the figures and tables. Final editing of the manuscript was done by GCS and GWB. All authors discussed, read, and approved the final manuscript.

\section{Compliance with ethical standards}

Conflict of Interest The authors declare no conflicts of interest.

Ethical approval All applicable international, national, and/or institutional guidelines for the care and use of animals were followed.

\section{References}

Ainley DG, Pauly D (2014) Fishing down the food web of the Antarctic continental shelf and slope. The Polar Rec 50: 92-107. https://doi.org/10.1017/S0032247412000757

Arkhipkin A, Brickle P, Laptikhovsky V (2003) Variation in the diet of the Patagonian toothfish with size, depth and season around the Falkland Islands. J Fish Biol 63: 428-441. https://doi.org/10.1046/j.10958649.2003.00164.x

Barrera-Oro ER, Casaux RJ, Marschoff ER. (2005) Dietary composition of juvenile Dissostichus eleginoides (Pisces, Nototheniidae) around Shag Rocks and South Georgia, Antarctica. Polar Biol 28: 637-641. https://doi.org/10.1007/s00300-005-0723-8

Brooks CM, Andrews AH, Ashford JR, Ramanna N, Jones CD, Lundstrom CC, Cailliet GM (2011) Age estimation and lead-radium dating of Antarctic toothfish (Dissostichus mawsoni) in the Ross Sea. Polar Biol 34: 329-338. https://doi.org/10.1007/s00300-010-0883-z

Calhaem I, Christoffel DA (1969) Some observations of the feeding habits of a Weddell seal, and measurements of its prey, Dissostichus mawsoni, at McMurdo Sound, Antarctica. N Z J Mar Freshwater Res, 3: 181-190. https://doi.org/10.1080/00288330.1969.9515287 
Collins MA, Ross KA, Belchier M, Reid K (2007) Distribution and diet of juvenile Patagonian toothfish on the South Georgia and Shag Rocks shelves (Southern Ocean). Mar Biol 152: 135-147. https://doi.org/10.1007/s00227-007-0667-3

Drazen JC, Sutton TT (2017) Dining in the deep: the feeding ecology of deep-sea fishes. Ann Rev Mar Sci 9: 337-366. https://doi.org/10.1146/annurev-marine-010816-060543

Evseenko SA, Kock KH, Nevinsky MM (1995) Early life history of the Patagonian toothfish, Dissostichus eleginoides Smitt, 1898 in the Atlantic sector of the Southern Ocean. Antarct Sci 7: 221-226. https://doi.org/10.1017/S0954102095000319

Fenaughty JM, Stevens DW, Hanchet SM (2003) Diet of the Antarctic toothfish (Dissostichus mawsoni) from the Ross Sea, Antarctica (subarea 88.1). CCAMLR Science 10: 113-123.

Fretwell PT, LaRue MA, Morin P, Kooyman GL, Wienecke B, Ratcliffe N, Fox AJ, Fleming AH, Porter C, Trathan PN (2012) An emperor penguin population estimate: the first global, synoptic survey of a species from space. PLoS One 7: e33751. https://doi.org/10.1371/journal.pone.0033751

de la Rosa SBG, Sanchez F, Figueroa D (1997) Comparative feeding ecology of Patagonian toothfish (Dissostichus eleginoides) in the southwestern Atlantic. CCAMLR Science 4: 105-124.

Gerking SD (1994) Feeding ecology of fish. Academic Press, San Diego.

Goldsworthy SD, Lewis M, Williams R, He X, Young JW, Van den Hoff J (2002) Diet of Patagonian toothfish (Dissostichus eleginoides) around Macquarie Island, South Pacific Ocean. Mar Freshw Res 53: 49-57. https://doi.org/10.1071/mf00075

Gon O, Heemstra PC (eds) (1990) Fishes of the Southern Ocean. JLB Smith Institute of Ichthyology, Grahamstown

Hanchet S, Dunn A, Parker S, Horn P, Stevens D, Mormede S (2015) The Antarctic toothfish (Dissostichus mawsoni): biology, ecology, and life history in the Ross Sea region. Hydrobiologia 761: 397-414. https://doi.org/10.1007/s10750-015-2435-6

Hanchet S, Sainsbury K, Butterworth D, Darby C, Bizikov V, Rune Godø O, Ichii T, Kock KH, López Abellán L, Vacchi M (2015) CCAMLR's precautionary approach to management focusing on Ross Sea toothfish fishery. Antarctic Sci 27: 333. https://doi.org/10.1017/S095410201400087X

Hanchet SM, Mormede S (2010) Distribution and relative abundance of Antarctic toothfish (Dissostichus mawsoni) on the Ross Sea shelf. CCAMLR Science 17: 33-51.

Huh SH, Lee DJ, Choo HG, Park JM, Baeck GW (2010) Feeding habits of olive flounder (Paralichthys olivaceus) collected from coastal waters off Taean, Korea. Korean J Fish Aquat Sci 43: 756-759. 
Huh SH, Nam KM, Park JM, Jeong JM, Baeck GW (2012) Feeding habits of the marbled flounder, Pleuronectes yokohamae in the coastal waters off Tongyeong, Korea. Korean J Ichthyol 24: 77-83.

Jo HS, Yeon I, Lim C (2013) Fatty acid and stable isotope analyses to infer diet of Antarctic toothfish caught in the southern Ross Sea. CCAMLR Science 20: 1-19.

Kock KH (1992) Antarctic fish and fisheries. University Press, Cambridge

Kock KH (2001) The direct influence of fishing and fishery-related activities on non-target species in the Southern Ocean with particular emphasis on longline fishing and its impact on albatrosses and petrels-a review. Rev Fish Biol Fish 11: 31-56. https://doi.org/10.1023/A:1014207719529

Kokorin NV (2010) The analysis of activeness and composition of food items of the Antarctic toothfish Dissostichus mawsoni (Nototheniidae) in Ross and Amundsen Seas during the 2006-2007 fishing season. Problems of Fisheries 11: 48-59.

Kooyman GL, Kooyman TG (1995) Diving behavior of emperor penguins nurturing chicks at Coulman Island, Antarctica. Condor 97: 536-549. https://doi.org/10.2307/1369039

Marshall NB (1965) Systematic and biological studies of the macrourid fishes (Anacanthini-Teleostii). Deep Sea Research and Oceanographic Abstracts 12: 299-322.

McLellan T (1977) Feeding strategies of the macrourids. Deep Sea Research 24: 1019-1036. https://doi.org/10.1016/0146-6291(77)90572-0

Melnychuk MC, Peterson E, Elliott M, Hilborn R (2017) Fisheries management impacts on target species status. Proc Natl Acad Sci U S A 114: 178-183. https://doi.org/10.1073/pnas.1609915114

Pakhomov EA, Tseytlin VB (1992) Diet of seven species of Antarctic fishes and estimation of their daily rations. Journal of Ichthyology 32: 138-146.

Park HJ, Yeon I, Lee YJ, Han E, Lee YJ, Hanchet SM, Baeck GW, Kwon Y, Choi SG, Lee DW, Kang CK (2015) Diet study of Antarctic toothfish caught in the east Antarctic based on stomach content, fatty acid and stable isotope analyses. CCAMLR Science 22: 29-44.

Petrov AF, Tatarnikov VA (2011) Results of investigation of the diet of Antarctic toothfish Dissostichus mawsoni (Nototheniidae) in the Lazarev Sea. J Ichthyol 51: 131-135.

https://doi.org/10.1134/S0032945210051017

Péron C, Welsford DC, Ziegler P, Lamb TD, Gasco N, Chazeau C, Sinègre R, Duhamel G (2016). Modelling spatial distribution of Patagonian toothfish through life-stages and sex and its implications for the 
fishery on the Kerguelen Plateau. Prog Oceanogr 141: 81-95.

https://doi.org/10.1016/j.pocean.2015.12.003

Pilling GM, Purves MG, Daw TM, Agnew DA, Xavier JC (2001) The stomach contents of Patagonian toothfish around South Georgia (South Atlantic). J Fish Biol 59: 1370-1384.

https://doi.org/10.1006/jfbi.2001.1748

Pinkas L, Oliphant MS, Iverson ILK (1971) Food habits of albacore, bluefin tuna and bonito in California waters. Fisheries Bulletin 152: 1-105.

Pinkerton MH, Bradford-Grieve JM (2014) Characterizing foodweb structure to identify potential ecosystem effects of fishing in the Ross Sea, Antarctica. ICES J Mar Sci 71: 1542-1553.

https://doi.org/10.1093/icesjms/fst230

Pinkerton MH, Bradford-Grieve JM, Hanchet SM (2010) A balanced model of the food web of the Ross Sea, Antarctica. CCAMLR Science 17: 1-31.

Pinkerton MH, McMillan P, Forman J (2013) Distribution, morphology and ecology of Macrourus whitsoni and M. cam/ (Gadiformes, Macrouridae) in the Ross Sea region. CCAMLR Science 20: 37-61.

Roberts J, Xavier JC, Agnew DJ (2011) The diet of toothfish species Dissostichus eleginoides and Dissostichus mawsoni with overlapping distributions. J Fish Biol 9: 138-154.

https://doi.org/10.1111/j.1095-8649.2011.03005.x

Sallaberry-Pincheira P, Galvez P, Molina-Burgos BE, Fernandoy F, Melendez R, Klarian SA (2018) Diet and food consumption of the Patagonian toothfish (Dissostichus eleginoides) in South Pacific Antarctic waters. Polar Biol 41: 2379-2385. https://doi.org/10.1007/s00300-018-2360-z

Schoener TW (1970) Nonsynchronous spatial overlap of lizards in patchy habitats. Ecology 51: 408-418.

https://doi.org/10.2307/1935376

Stevens DW, Dunn MR, Pinkerton MH, Forman JS (2014) Diet of Antarctic toothfish (Dissostichus mawsoni) from the continental slope and oceanic features of the Ross Sea region, Antarctica. Antarct Sci 26: 502-512. https://doi.org/10.1017/S095410201300093X

Taki K, Kiyota M, Ichii T, Iwami T (2011) Distribution and population structure of Dissostichus eleginoides and D. Mawsoni on BANZARE Bank (CCAMLR Division 58.4. 3b), Indian Ocean. CCAMLR Science 18: 145153.

Wallace Jr RK (1981) An assessment of diet-overlap indexes. Transactions of the american fisheries society 110: 72-76. https://doi.org/10.1577/1548-8659(1981)110\%3C72:AAODI\%3E2.0.CO;2 
Xavier JC, Rodhouse PG, Purves MG, Daw TM, Arata J, Pilling GM (2002) Distribution of cephalopods recorded in the diet of the Patagonian toothfish (Dissostichus eleginoides) around South Georgia. Polar Biol 25: 323-330. https://doi.org/10.1007/s00300-001-0343-x

Yates P, Ziegler P, Welsford D, Wotherspoon S, Burch P, Maschette D (2019) Distribution of Antarctic toothfish Dissostichus mawsoni along East Antarctica: Environmental drivers and management implications. Fish Res 219: 105338. https://doi.org/10.1016/j.fishres.2019.105338

Yoon TH, Kang HE, Lee SR, Lee JB, Baeck GW, Park H, Kim HW (2017) Metabarcoding analysis of the stomach contents of the Antarctic Toothfish (Dissostichus mawsoni) collected in the Antarctic Ocean. PeerJ 5: e3977. https://doi.org/10.7717/peerj.3977

Yukhov VL (1971) The range of Dissostichus mawsoni Norman and some features of its biology. Journal of Ichthyology 11: 14-25.

\section{Tables}

Table 1 Composition of the stomach contents of Dissostichus mawsoni caught along the East Antarctic continental slope by frequency of occurrence $(\% F)$, number $(\% N)$, wet weight $(\% W)$, and index of relative importance $(\% I R I)$. 


\begin{tabular}{|c|c|c|c|c|}
\hline Prey items & $\% F$ & $\% N$ & $\% W$ & \%IRI \\
\hline Crustacea & 5.7 & 3.9 & 0.2 & 0.1 \\
\hline Amphipoda & 0.3 & 0.2 & + & \\
\hline Decapoda & 3.8 & 2.0 & 0.2 & \\
\hline Macrura & 3.8 & 2.0 & 0.2 & \\
\hline Isopoda & 1.7 & 1.8 & 0.1 & \\
\hline Mollusca & 18.3 & 13.4 & 3.9 & 1.9 \\
\hline Cephalopoda & 17.5 & 12.6 & 3.8 & \\
\hline Gastropoda & 1.1 & 0.8 & 0.1 & \\
\hline Pisces & 92.5 & 77.8 & 94.5 & 97.8 \\
\hline Anotopteridae & 0.3 & 0.2 & 0.2 & \\
\hline Anotopterus pharao & 0.3 & 0.2 & 0.2 & \\
\hline Bathydraconidae & 0.6 & 0.3 & 0.1 & \\
\hline Bathydraco marri & 0.6 & 0.3 & 0.1 & \\
\hline Channichthyidae & 12.4 & 9.8 & 11.2 & \\
\hline Chaenodraco wilsoni & 0.3 & 0.2 & 0.1 & \\
\hline Chionobathyscus dewitti & 12.1 & 9.7 & 11.1 & \\
\hline Macrouridae & 39.8 & 27.6 & 61.1 & \\
\hline Coryphaenoides sp. & 0.2 & 0.1 & 0.1 & \\
\hline Unidentified Macrouridae & 39.7 & 27.5 & 61.0 & \\
\hline Moridae & 0.3 & 0.2 & 0.7 & \\
\hline Antimora rostrata & 0.3 & 0.2 & 0.7 & \\
\hline Muraenolepididae & 0.5 & 0.2 & 0.4 & \\
\hline Muraenolepis spp. & 0.5 & 0.2 & 0.4 & \\
\hline Nototheniidae & 8.3 & 5.4 & 4.5 & \\
\hline Trematomus hansoni & 5.2 & 3.5 & 3.4 & \\
\hline T. loennbergii & 0.2 & 0.1 & 0.1 & \\
\hline Unidentified Nototheniidae & 3.0 & 1.8 & 1.0 & \\
\hline Paralepididae & 1.3 & 0.7 & 1.1 & \\
\hline Arctozenus risso & 1.3 & 0.7 & 1.1 & \\
\hline Zoarcidae & 2.4 & 1.3 & 0.5 & \\
\hline Pachycara brachycephalum & 2.1 & 1.1 & 0.5 & \\
\hline Unidentified Zoarcidae & 0.3 & 0.2 & + & \\
\hline Unidentified Pisces & 51.1 & 32.2 & 14.5 & \\
\hline Anthozoa & 0.2 & 0.1 & + & + \\
\hline Aves & 0.6 & 0.3 & 1.2 & + \\
\hline Diomedeidae & 0.2 & 0.1 & 0.2 & \\
\hline Spheniscidae & 0.5 & 0.2 & 1.0 & \\
\hline Aptenodytes forsteri & 0.5 & 0.2 & 1.0 & \\
\hline Echinodermata & 0.5 & 0.5 & + & + \\
\hline Asteroidea & 0.2 & 0.1 & + & \\
\hline Ophiuroidea & 0.3 & 0.5 & + & \\
\hline Egg mass & 0.2 & 0.1 & + & + \\
\hline Mammalia & 0.3 & 0.2 & + & + \\
\hline Stone & 5.4 & 3.7 & 0.2 & 0.1 \\
\hline Total & & 100.0 & 100.0 & 100.0 \\
\hline
\end{tabular}


Table 2 Proportional diet overlap coefficients (Schoener's index) of Dissostichus mawsoni caught along the East Antarctic continental slope in terms of total prey among size classes ( $<100 \mathrm{~cm}, n=14 ; 100-120 \mathrm{~cm}, n=49 ; 120-$ $140 \mathrm{~cm}, n=145 ; 140-160 \mathrm{~cm}, n=338 ; \geq 160 \mathrm{~cm}, n=84)$. BL, body length.

\begin{tabular}{clccc}
\hline Size class $(\mathrm{cm}, \mathrm{BL})$ & $<100$ & $100-120$ & $120-140$ & $140-160$ \\
\hline $100-120$ & 0.91 & & & \\
$120-140$ & 0.98 & 0.93 & & \\
$140-160$ & 0.99 & 0.91 & 0.99 & \\
$\geq 160$ & 0.96 & 0.90 & 0.96 & 0.97 \\
\hline
\end{tabular}

Table 3 Proportional diet overlap coefficients (Schoener's index) of Dissostichus mawsoni caught along the East Antarctic continental slope for the dominant prey item (fishes) among size classes ( $<100 \mathrm{~cm}, n=5 ; 100-120 \mathrm{~cm}$, $n=19 ; 120-140 \mathrm{~cm}, n=74 ; 140-160 \mathrm{~cm}, n=210$; $\geq 160 \mathrm{~cm}, n=47)$. BL, body length.

\begin{tabular}{ccccc}
\hline Size class $(\mathrm{cm}, \mathrm{BL})$ & $<100$ & $100-120$ & $120-140$ & $140-160$ \\
\hline $100-120$ & 0.59 & & & \\
$120-140$ & 0.55 & 0.84 & & \\
$140-160$ & 0.45 & 0.76 & 0.87 & \\
$\geq 160$ & 0.33 & 0.63 & 0.76 & 0.85 \\
\hline
\end{tabular}

Figures 


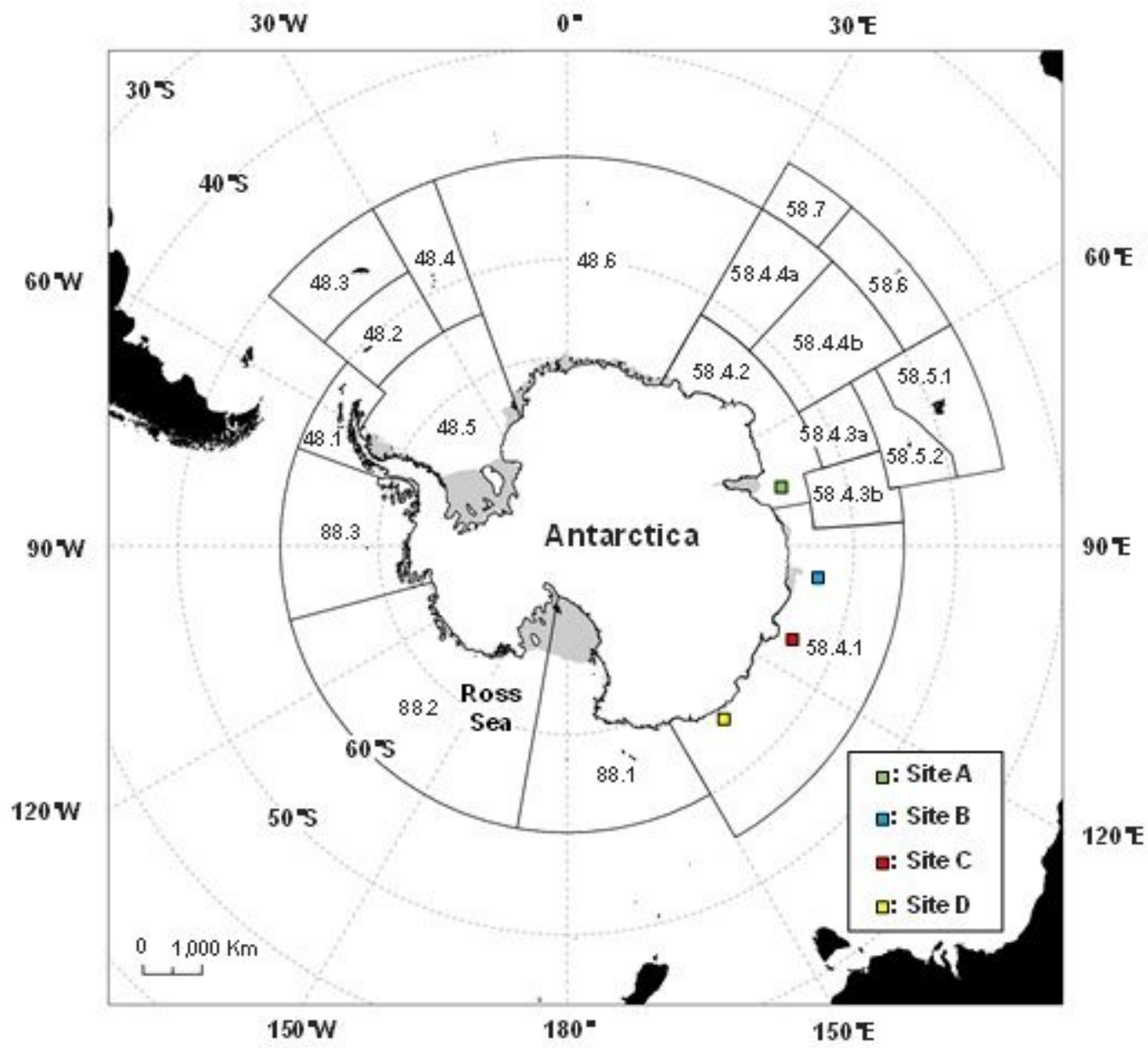

Figure 1

Sampling areas of Dissostichus mawsoni caught along the East Antarctic continental slope. Each site is marked with a colored square. 


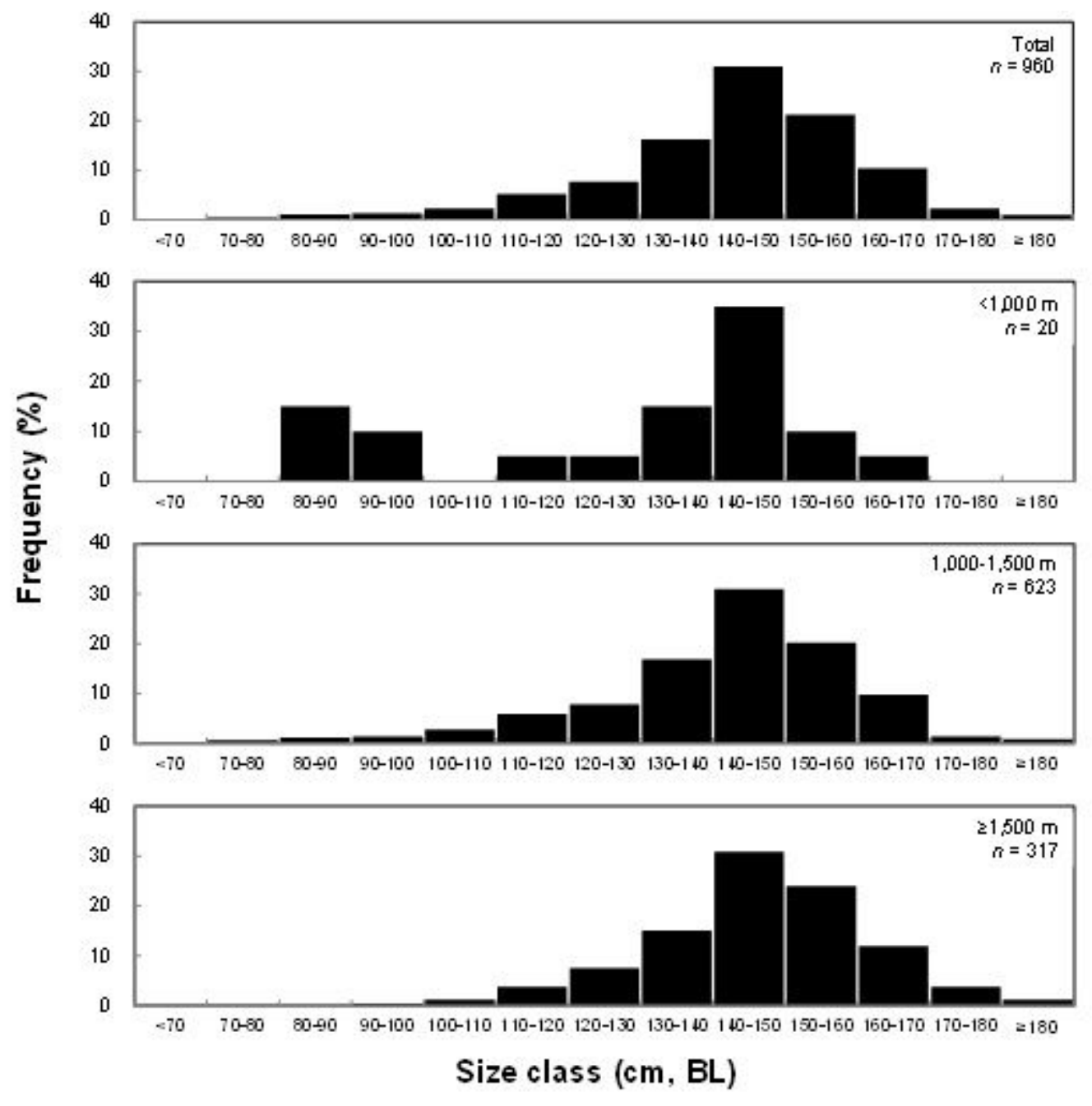

Figure 2

Length-frequency distribution of Dissostichus mawsoni caught along the East Antarctic continental slope. BL, body length. 


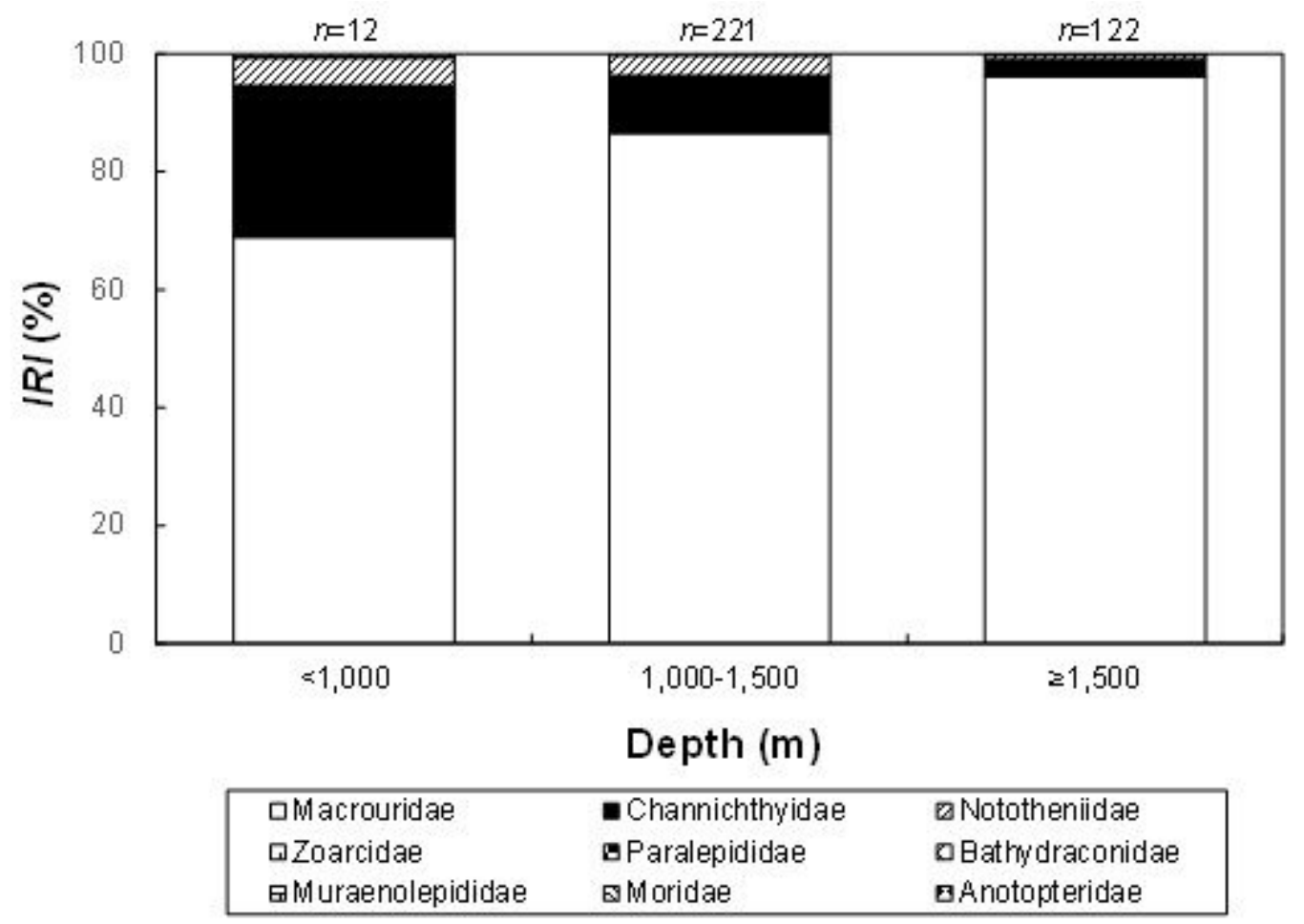

\section{Figure 3}

Diet composition of the dominant prey item (fishes) of Dissostichus mawsoni caught along the East Antarctic continental slope based on the index of relative importance (\%IRI) by depth $(<1,000 \mathrm{~m}, \mathrm{n}=12$; $1,000-1,500 \mathrm{~cm}, \mathrm{n}=221 ; \geq 1,500 \mathrm{~cm}, \mathrm{n}=122$ ).

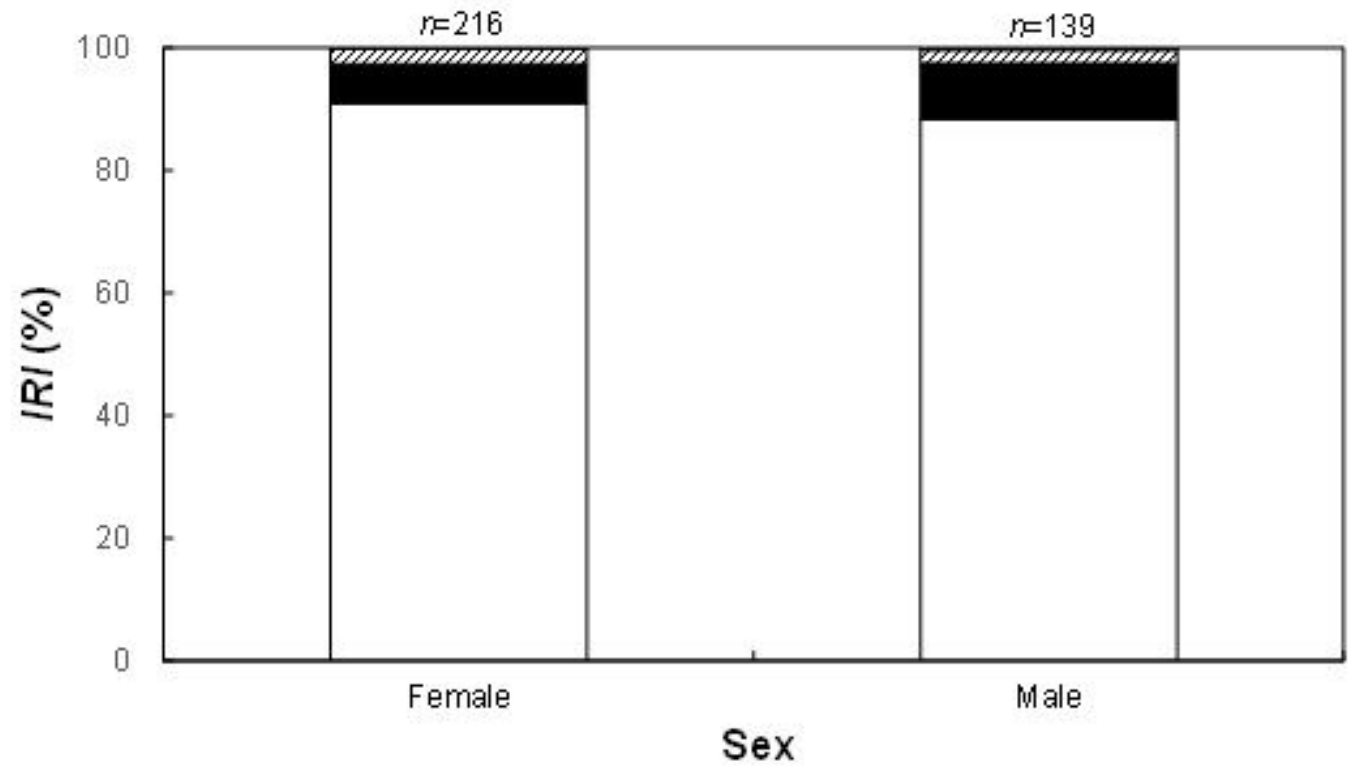

Figure 4 
Diet composition of the dominant prey item (fishes) of Dissostichus mawsoni caught along the East Antarctic continental slope based on the index of relative importance (\%IRI) by sex (female, $n=216$; male, $n=139)$.

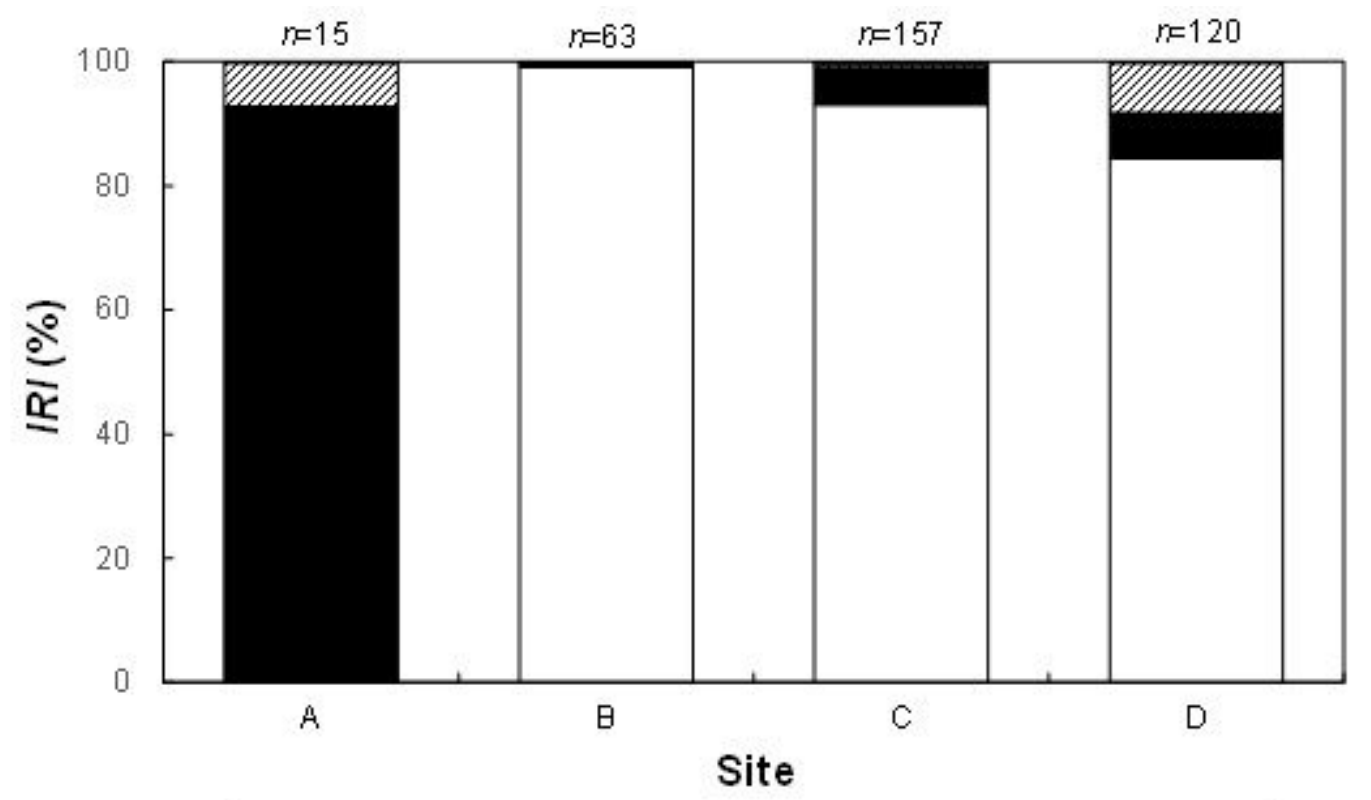

\begin{tabular}{|c|c|c|}
\hline 口Macrouridae & -Channichtlyidae & 口Nototheniidae \\
\hline a Zoarcidae & - Paralepididae & ص日athydraconidae \\
\hline a Muraenolepididae & घMoridae & AAnotopteridae \\
\hline
\end{tabular}

\section{Figure 5}

Diet composition of the dominant prey item (fishes) of Dissostichus mawsoni caught along the East Antarctic continental slope based on the index of relative importance (\%IRI) by site $(A, n=15 ; B, n=63 ; C$, $n=157 ; D, n=120)$.

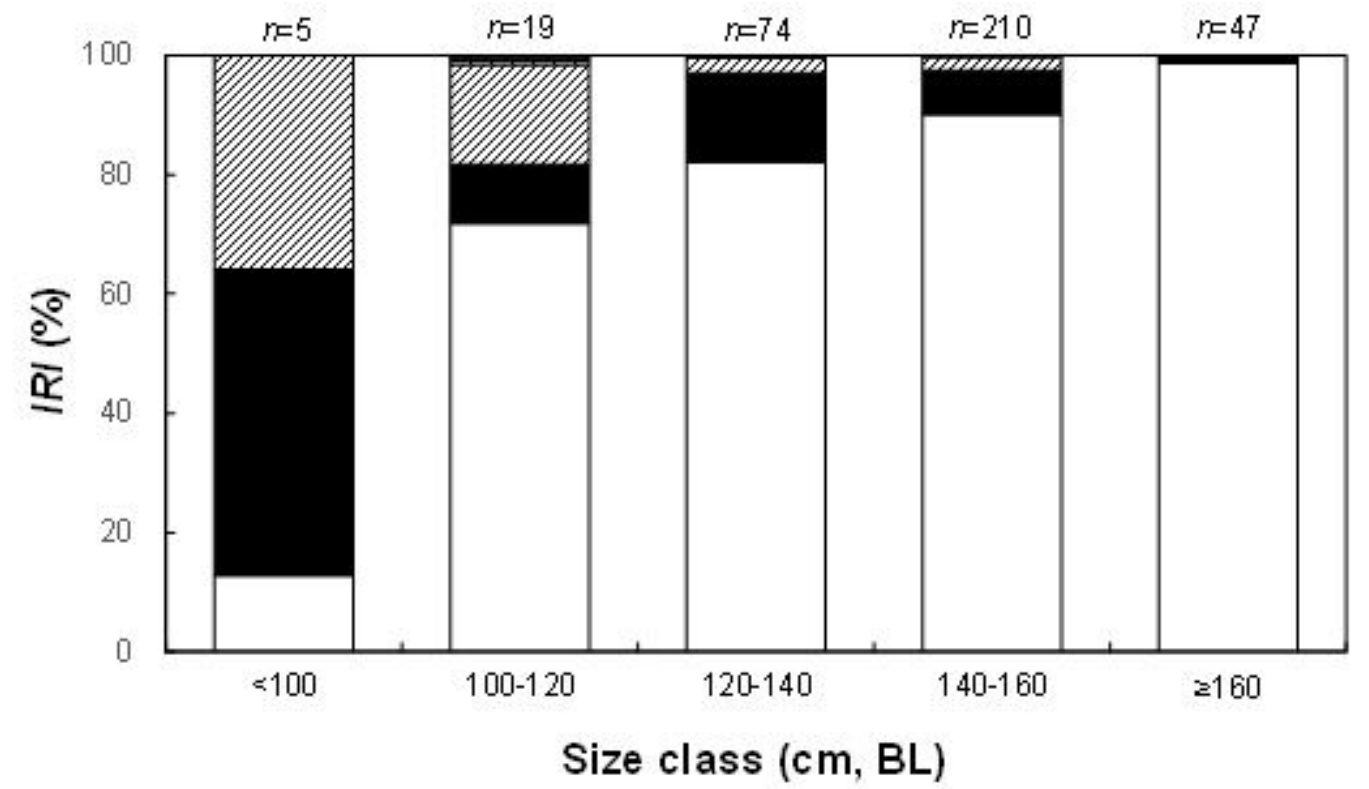

\begin{tabular}{|c|c|c|}
\hline $\begin{array}{l}\text { 口Macrouridae } \\
\text { cZoarcidae } \\
\text { aM uraenolepididae }\end{array}$ & $\begin{array}{l}\text { - Channichthyidae } \\
\text { a Paralepididae } \\
\text { a M oridae }\end{array}$ & $\begin{array}{l}\text { घNototheniidae } \\
\text { ఐathydraconidae } \\
\text { ■Anotopteridae }\end{array}$ \\
\hline
\end{tabular}


Figure 6

Ontogenetic changes in composition of the dominant prey item (fishes) of Dissostichus mawsoni caught along the East Antarctic continental slope based on the index of relative importance (\%IRI) among size classes ( $<100 \mathrm{~cm}, \mathrm{n}=5 ; 100-120 \mathrm{~cm}, \mathrm{n}=19 ; 120-140 \mathrm{~cm}, \mathrm{n}=74 ; 140-160 \mathrm{~cm}, \mathrm{n}=210 ; \geq 160 \mathrm{~cm}, \mathrm{n}=47)$. BL, body length.

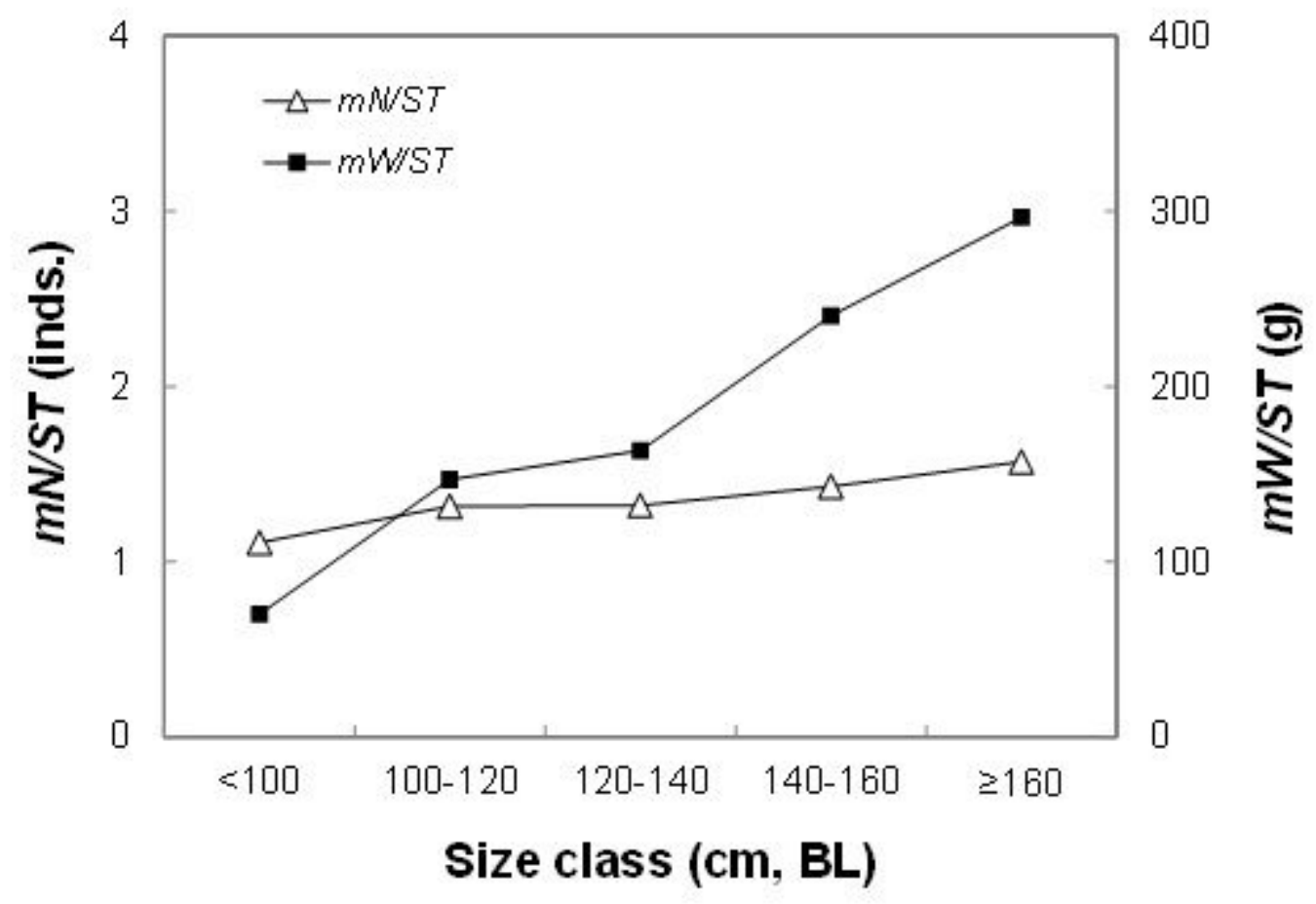

Figure 7

Differences in the mean number of prey items per stomach (mN/ST, individuals/stomach) and mean wet weight of prey per stomach (mW/ST, g/stomach) of Dissostichus mawsoni caught along the East Antarctic continental slope among size classes $(<100 \mathrm{~cm}, n=14 ; 100-120 \mathrm{~cm}, n=49 ; 120-140 \mathrm{~cm}, \mathrm{n}=145$; $140-160 \mathrm{~cm}, \mathrm{n}=338 ; \geq 160 \mathrm{~cm}, \mathrm{n}=84)$. BL, body length. 